\title{
APLIKASI BREAK EVEN POINT PADA PEMBUATAN ROTI Studi Kasus: Usaha Kecil Menengah (UKM) Roti (Rotiku Rotimu) Desa Babakan
}

\author{
Made Wijana*, AA Alit Triadi", Muhammad Kholiq ${ }^{* *}$ \\ *Dosen, Jurusan Teknik Mesin Fakultas Teknik Universitas Mataram \\ Jl. Majapahit No. 62 Mataram, Nusa Tenggara Barat \\ Telpon. (0370) 636126, Fax. (0370) 636523 \\ **Mahasiswa, Jurusan Teknik Mesin Fakultas Teknik Universitas Mataram \\ Jl. Majapahit No. 62 Mataram, Nusa Tenggara Barat \\ Telpon. (0370) 636126, Fax. (0370) 636523
}

\begin{abstract}
In recent years many companies both micro and macro level national and international emerging. As UKM (Usaha Kecil Menengah) have an important role in opening new jobs and boost economic growth of a region. With the development of business world has been brought towards the increasingly fierce competition. That businesses are required to conduct an economic analysis that can help entrepreneurs to consider actions proposed in choosing the alternatives or strategic decision.

This research aimed to analyze the feasibility of the operation of UKM bread (my bread your bread) Babakan Village by using BEP (Break Even Point).Location research Babakan Village, District Cakranegara, West Lombok. By collecting various kinds of costs of making bread among other fixed costs and variable costs as well as to record income from the sale of bread in a period of 1 year. Examples of fixed costs is the cost of equipment, maintenance costs, the cost of building and examples of variable costs is the cost of raw materials, the cost of operation of the device, the cost of salaries, the cost of packaging.

The results of this research indicate that UKM income Bread (my bread your bread) for 1 year is Rp. 912,000,000.00 of the total production of 1.14 million pieces of bread. This UKM bread achieve the BEP (Break Even Point) occurred in the month 4th at a fixed cost is Rp.30,250,733,33 and VC (Variable Cost) is Rp.212,240,114,71 on the amount of bread produced 303114 fruit bread with a TC (total cost) Rp.242,490,848.04. So that UKM Bread (my bread your bread) feasible to be operated. With the increase in the selling price of Rp.850.00 fried bread resulting increase in profit of Rp57,000,000.00 while the selling price of Rp.750.00 fried bread resulted in a decrease in profit of Rp.57,000,000.00 while equally produce 1.14 million pieces bread. By lowering the variable costs, employers can accelerate the achievement of breakeven levels (Break Even Point).
\end{abstract}

Keywords: UKM, Break Even Point, Quantityof product, Cost, Profit.

\section{PENDAHULUAN}

\subsection{Latar Belakang}

Tujuan mendirikan usaha tidak lain adalah untuk memperoleh keuntungan yang dapat dipergunakan untuk kelangsungan hidup. Kemajuan dan perkembangan usaha akan membawa akibat bagi pembangunan itu sendiri baik positif maupun negatif . Pada kalangan pengusaha itu sendiri, perkembangan dan kemajuan dunia usaha telah membawa kearah persaingan yang semakin ketat, sedangkan usaha untuk mencapai laba tidak dapat dipisahkan dari masalah penjualan, peningkatan penjualan yang tinggi bukan selalu berarti mendapatkan laba yang lebih besar.[8]

Analisis break even point dilakukan untuk melihat kinerja dari perusahaan itu sendiri, memberikan wawasan mengenai seberapa pentingnya melakukan pembukuan keuangan dan analisis ekonomi teknik yang dapat membantu pengusaha dalam mengambil tindakan-tindakan yang diusulkan dalam mempertimbangan alternatif-alternatif atau tujuan pengambilan keputusan yang mampu meningkatkan daya saing perusahaan.

Dikarenakan banyak usaha kecil menengah (UKM) dari awal membuka usahanya hingga sekarang belum pernah melakukan analisa perhitungan untung rugi dan perhitungan secara konprehensif berapa unit produk semestinya yang dibuat agar usaha tersebut balik modal dengan melihat faktor produksi atau sumber daya yang digunakan. 


\subsection{Rumusan Masalah}

Berdasarkan latar belakang, maka dapat dirumuskan suatu permasalahan bagaimana untuk menganalisis keuangan dari usaha kecil menengah (UKM) dengan menggunakan metode analisa break even point (BEP) sehingga UKM mampu untuk mengatur strategi keuangan perusahaan dan meningkatkan daya saing di dunia bisnis.

\subsection{Batasan Masalah}

Pada penelitian ini, penulis membatasi permasalahan-permasalahan sebagai berikut:

1. Asumsi ukuran adonan dianggap sama

2. Jumlah produk yang dihasilkan tiap bulan diambil rata-rata

3. Peneliti hanya mengambil produk roti goreng

4. Harga bahan baku pada toko langganan konstan.

5. Harga jual produk Rp.750,00,Rp.800,00,- dan Rp.850,00.-

6. Diasumsikan produk yang dihasilkan tiap harinya habis terjual

\subsection{Tujuan Penelitian}

Dalam proses pengerjaan tugas akhir ini mempunyai tujuan sebagai berikut:

1. Mengetahui jumlah produk yang dihasilkan saat kondisi Break Even Point (BEP).

2. Mengetahui rentang waktu hingga mencapai Break Even Point (BEP).

3. Mengetahui kelayakan beroperasinya UKM Roti (Rotiku Roimu) menggunakan metode Break Event Point (BEP).

4. Mengetahui tingkat penjualan yang harus dicapai apabila harga jual roti goreng mengalami penurunan ataupun kenaikan.

5. Mengetahuipengaruh apabila biaya tidak tetap (variabel cost) diturunkan.

\subsection{Manfaat Penelitian}

Adapun manfaat penelitian penulisan tugas akhir ini adalah:

1. Dapat mengetahui bagaimana metode Break Even Point (BEP) dapat menjadi tolak ukur perusahaan dalam menentukan langkah yang diambil demi kelancaran produksi dan penjualan perusahaan.

2. Dapat membantu perusahaan untuk mengetahui bagaimana cara menganalisa biaya, volume dan laba dalam menanggapi peluang-peluang yang ada pada perusahaan.

3. Dapat membantu perkembangan perusahaan untuk kedepannya.

1.6 Tempat penelitian
Penelitian ini dilakukan di perusahaan roti (Rotiku Rotimu) di wilayah Desa Babakan yang berada di Kecamatan Cakra Negara, Kabupaten Lombok Barat, Nusa Tenggara Barat.

\section{LANDASAN TEORI \\ 2.1 Meningkatkan Daya Saing UKM}

Pendekatan strategi yang dimunculkan oleh Michael Porter (Chaniago, 2008) dalam meningkatkan daya saing UKM di Indonesia adalah di mana strategi itu terbagi atas 3, yaitu pada:

1. Cost leadership (Keunggulan Biaya)

Berusaha untuk memenangkan persaingan dengan pendekatakan harga, dimana dengan harga tertentu akan produk yang dihasilkannya konsumen lebih tertarik untuk membeli produk tersebut.

\section{Differentiation (Product Unique)}

Untuk memenangkan persaingan bisnis, perusahaan berusaha membuat produk yang unik, dimana produk tersebut sulit ditiru oleh pesaing perusahaan.

\section{Focus/Competifines Strategy}

Strategi ini memfokuskan kegiatan pada konsumen dengan segmen tertentu. Pengincaran konsumen segmen tertentu ini akan lebih memudahkan perusahaan untuk memenangkan persaingan bisnis.

\subsection{Pengertian Analisa Break Even Point (Titik Impas)}

Break event point atau titik impas Menurut Pujawan (2004) dalam bukunya yang berjudul "Ekonomi Teknik", Analisis Break Even Point adalah salah satu analisa dalam ekonomi teknik yang sangat popular digunakan terutama pada sektor-sektor industri yang padat karya. Analisa ini akan berguna apabila seorang akan mengambil keputusan pemilihan alternatif yang cukup sensitif terhadap parameter atau variabel dan bila variabel-variabel tersebut sulit diestimasi nilainya.[9]

Dengan mengatahui titik impasnya (Break even point) manajer suatu perusahaan dapat mengindikasikan tingkat penjualan yang disyaratkan agar terhindar dari kerugian, dan diharapkan dapat mengambil langkah-langkah yang tepat untuk masa yang akan datang.

\subsection{Kegunaan dan Aplikasi Break Even Point (Titik Impas)}

Menurut Alwi (1994) bahwa analisa break even point dapat membantu pimpinan dalam mengambil keputusan antara lain:

1. Jumlah penjualan minimum yang harus dipertahankan agar perusahaan tidak mengalami kerugian. 
2. Jumlah penjualan yang harus dicapai untuk memperoleh keuntungan tertentu.

3. Seberapa jauhkah berkurangnya penjualan agar perusahaan tidak menderita rugi.

4. Untuk mengetahui bagaimana efek perubahan harga jual, biaya dan volume penjualan terhadap keuntungan yang akan diperoleh.[1]

Menurut Harahap (2008) dalam

analisis laporan keuangan kita dapat menggunakan rumus break even point :

1. Untuk mengetahui hubungan antara penjualan, biaya, dan laba.

2. Untuk mengetahui struktur biaya tetap dan biaya variabel.

3. Untuk mengetahui kemampuan perusahaan dalam menekan biaya dan batas dimana perusahaan tidak mengalami laba dan rugi.

4. Untuk mengetahui hubungan antara cost, volume, harga dan laba.[5]

\subsection{Jenis-Jenis Biaya Dalam analisa} Break Even Point

Pada dasarnya biaya merupakan titik tolak dalam menetapkan harga jual suatu produk yang dihasilkan. Yang dimaksud dengan biaya adalah pengorbanan sumber ekonomi, yang diukur dalam satuan uang, yang telah terjadi atau yang kemungkinan akan terjadi untuk tujuan tertentu. Dalam analisa titik impas, seringkali fungsi biaya maupun fungsi pendapatan diasumsikan linier terhadap volume produksi. Ada tiga komponen biaya yang dipertimbangkan dalam analisa ini, yaitu :

\subsubsection{Biaya Tetap}

Menurut Hansen dan Mowen yang dialih bahasakan oleh Hermawan (2000) biaya tetap adalah biaya yang tetap sama dalam jumlah seiring dengan kenaikan atau penurunan keluaran kegiatan.

Adapun biaya tersebut meliputi:
1. Gaji
4. Sewa
2. Penyusutan
5. Bunga utang
3. Asuransi
6. Biaya kantor

\subsubsection{Biaya Variabel}

Menurut Hansen dan Mowen yang dialih bahasakan oleh Hermawan (2000) biaya variabel adalah biaya yang meningkat dalam total seiring dengan peningkatan keluaran kegiatan dan menurun dalam total seiring dengan penurunan keluaran kegiatan. Biaya variabel itu antara lain adalah sebagai berikut:
1. Bahan baku 4. Biaya produksi

2. Upah buruh 5. Biaya pemasaran langsung

3. Kondisi penjualan

\subsubsection{Biaya Total}

Kesimpulan biaya total menurut penulis adalah jumlah dari keseluruhan biaya-biaya yang harus atau akan dikeluarkan dari jumlah kedua biaya variable dan biaya tetap atas hasil produksi yang dihasilkan atau akan direncanakan.

\subsection{Menentukan Break Even Point (Titik Impas)}

Alat analisa yang dapat digunakan dalam mencari tingkat break even point adalah:

1 Pendekatan Matematika

Perhitungan break even point dalam unit dapat dilakukan dengan menghitung rumus:

$$
\operatorname{BEP}(\mathrm{X})=\frac{F C}{P-C}
$$

Perhitungan Break even point dalam rupiah dapat dilakukan dengan menggunakan rumus sebagai berikut:

Di mana:

$$
\operatorname{BEP}(p . \mathrm{X})=\frac{F C}{1-\frac{c}{p}}
$$

$$
\begin{aligned}
\mathrm{BEP}(\mathrm{X})= & \text { Break event point/Volume } \\
& \text { produksi dalam unit } \\
\mathrm{BEP}(\mathrm{p} . \mathrm{X})= & \text { Break even point/volume } \\
& \text { produksi dalam rupiah } \\
\mathrm{FC}= & \text { Fixed Cost/Biaya tetap }(\mathrm{Rp}) \\
\mathrm{F} & \text { Price/Harga jual per unit } \\
& \text { (Rp/Unit) } \\
= & \text { Cost/Biaya variabel untuk } \\
& \begin{array}{l}
\text { membuat satu unit produk } \\
\text { (Rp/Unit). }
\end{array}
\end{aligned}
$$

2. Dengan cara grafik

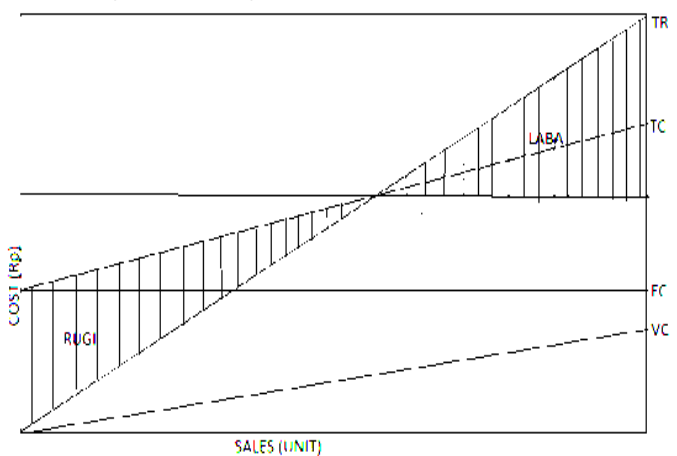

Gambar 2.4 Grafik BEP (Break Even Point) (Sumber: Pujawan,2004)

\section{METODE PENELITIAN} 3.1 Jenis Penelitian 
Penelitian ini menggunakan data kuantitatif dimana penulis akan melakukan pengumpulan data berupa angka yang dibutuhkan sehubungan dengan masalah yang akan diteliti, sehingga hasil penelitiannya dapat lebih dipercaya dan diandalkan kebenarannya.

\subsection{Penelusuran Pustaka}

Penulusuran pustaka di lakukan untuk mendapatkan gambaran klasifikasi biayabiaya dan cara-cara menganalisis dalam penelitian yang akan dilakukan.

\subsection{Pengambilan Data}

Melakukan Pengambilan data komponen biaya-biaya yang dibutuhkan dalam pembuatan roti (roti goreng) di wilayah Desa Babakan yaitu

1. Biaya tetap (fixed cost)
a. Biaya peralatan
b. Biaya perawatan
c. Biaya sewa bangunan

2. Biaya tidak tetap (variabel cost)
a. Biaya bahan baku
b. Biaya pengoperasian alat
c. Biaya gaji pegawai
d. Biaya pengemasan

\subsection{Pengolahan Data}

Memasukkan dan mengolah data-data yang akan diproleh ke dalam tabel-tabel biaya sehingga memudahkan analisis data yang akan di lakukan.

\subsection{Analisa Data dan Pembahasan}

Dalam menganalisa data di gunakan analisis metode BEP. Analisis BEP digunakan untuk menerangkan atau memberikan penjelasan data-data yang diperolah dari hasil penelitian. Berikut adalah rumus Break Even Point yang digunakan untuk mengetahui nilai impas :

1. Pendekatan matematika

$$
\begin{aligned}
& \operatorname{BEP}(\mathrm{X})=\frac{F C}{p-c} \\
& \operatorname{BEP}(p . \mathrm{X})=\frac{F C}{1-\frac{c}{p}}
\end{aligned}
$$

Dimana:

$$
\begin{aligned}
& \mathrm{BEP}(\mathrm{X})=\text { Break even point/volume } \\
& \text { produksi dalam unit } \\
& \mathrm{BEP}(\mathrm{p} . \mathrm{X})=\text { Break even point/volume } \\
& \text { produksi dalam rupiah } \\
& \mathrm{FC}=\text { Fixed cost/Biaya tetap (Rp) } \\
& P \quad=\text { Price/harga jual per unit (Rp/unit) } \\
& \text { C = Cost/biaya variabel untuk } \\
& \text { membuat satu unit produk } \\
& \text { (Rp/unit) }
\end{aligned}
$$

2. Dengan cara grafik

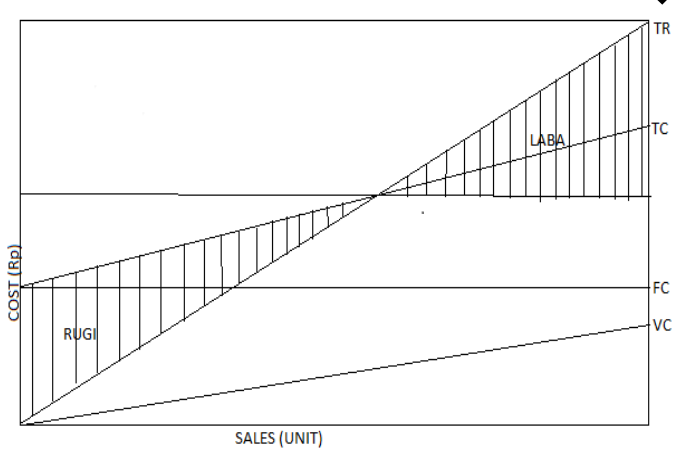

Gambar 3.1 Grafik BEP (Break Even Point)

\section{HASIL DAN PEMBAHASAN}

\subsection{Jumlah Produk Yang dihasilkan per Bulan Pada Tahun 2013}

Jumlah roti yang dihasilkan tiap bulannya berbeda-beda sebab dipengaruhi oleh hari libur / hari minggu dan juga harihari besar.

Tabel 4.1 Jumlah produk roti yang dihasilkan setiap bulannya

\begin{tabular}{clcc}
\hline No & Bulan & $\begin{array}{c}\text { Jumlah } \\
\text { hari kerja }\end{array}$ & $\begin{array}{c}\text { Jumlah roti yang } \\
\text { dihasilkan (buah) }\end{array}$ \\
\hline 1 & Januari & 23 & 92.000 \\
\hline 2 & Februari & 24 & 96.000 \\
\hline 3 & Maret & 26 & 104.000 \\
\hline 4 & April & 26 & 104.000 \\
\hline 5 & Mei & 26 & 104.000 \\
\hline 6 & Juni & 23 & 92.000 \\
\hline 7 & Juli & 18 & 72.000 \\
\hline 8 & Agustus & 18 & 72.000 \\
\hline 9 & September & 25 & 100.000 \\
\hline 10 & Oktober & 25 & 100.000 \\
\hline 11 & November & 25 & 100.000 \\
\hline 12 & Desember & 26 & 104.000 \\
\hline & Rata-rata & 23,75 & 95.000 \\
\hline
\end{tabular}

(Sumber: UKM Rotiku Rotimu, 2013)

\subsection{Analisis Biaya Pembuatan Roti Goreng \\ Biaya pembuatan roti terdiri dari biaya} tetap (fixed cost) dan biaya tidak tetap (variabel cost).

\subsubsection{Biaya Tetap (Fixed Cost)}

Biaya tetap (fixed cost) pada pembuatan roti (rotiku rotimu) adalah biaya yang dikeluarkan oleh pemilik industri yang dimana besar kecilnya tidak dipengaruhi oleh jumlah produksi atau pengeluarannya bersifat konstan selama proses produksi. 
Tabel 4.2 Biaya tetap (fixed cost) dalam pembuatan roti goreng pada perusahaan roti (rotiku rotimu)

\begin{tabular}{clc}
\hline No & $\begin{array}{c}\text { Biaya tetap (fixed } \\
\text { cost) }\end{array}$ & \multicolumn{2}{c}{ Nilai (Rp) } \\
\hline 1 & Biaya peralatan & Rp. $4.636 .733,33$ \\
\hline 2 & Biaya perawatan & Rp. $1.614 .000,00$ \\
\hline 3 & Biaya gedung & Rp. $24.000 .000,00$ \\
\hline & Total jumlah & Rp. $30.250 .733,33$ \\
\hline
\end{tabular}

Berdasarkan tabel 4.2 disimpulkan bahwa, Biaya tetap (Fixed Cost) pada pembuatan roti goreng adalah Rp.30.250.733,33.

\subsubsection{Biaya Tidak Tetap (Variabel Cost)}

Biaya tidak tetap adalah biaya yang dikeluarkan oleh pemilik perusahaan selama proses pembuatan roti berlangsung. Biaya tidak tetap terdiri dari biaya bahan baku, biaya pengoperasian mesin, biaya pengemasan, dan biaya gaji pegawai.

Tabel 4.3 Biaya tidak tetap (variabel cost) per roti dalam pembuatan roti goreng pada perusahaan roti (rotiku rotimu)

\begin{tabular}{lll}
\hline No & \multicolumn{1}{c}{$\begin{array}{c}\text { Biaya tidak tetap (varibel } \\
\text { cost) }\end{array}$} & Nilai (Rp) \\
\hline 1 & Biaya bahan baku & Rp. 402,54 \\
\hline 2 & Biaya pengoperasian alat & Rp. 137,66 \\
\hline 3 & Biaya gaji pegawai & Rp. 65,00 \\
\hline 4 & Biaya pengemasan & Rp. 95,00 \\
\hline & Total jumlah & Rp. 700,20 \\
\hline
\end{tabular}

Tabel 4.4 Biaya tidak tetap (variabel cost) dalam pembuatan roti goreng setiap bulannya pada perusahaan roti (rotiku rotimu)

\begin{tabular}{c|lrll}
\hline No & Bulan & $\begin{array}{c}\text { Jumlah } \\
\text { roti yang } \\
\text { dihasilkan } \\
\text { (buah) }\end{array}$ & & \\
\hline 1 & Januari & 92.000 & Rp. & 64.418 .400 .00 \\
\hline 2 & Februari & 96.000 & Rp. & 67.219 .200 .00 \\
\hline 3 & Maret & 104.000 & Rp. & 72.820 .800 .00 \\
\hline 4 & April & 104.000 & Rp. & 72.820 .800 .00 \\
\hline 5 & Mei & 104.000 & Rp. & 72.820 .800 .00 \\
\hline 6 & Juni & 92.000 & Rp. & 64.418 .400 .00 \\
\hline 7 & Juli & 72.000 & Rp. & 50.414 .400 .00 \\
\hline 8 & Agustus & 72.000 & Rp. & 50.414 .400 .00 \\
\hline 9 & September & 100.000 & Rp. & 70.020 .000 .00 \\
\hline 10 & Oktober & 100.000 & Rp. & 70.020 .000 .00 \\
\hline 11 & November & 100.000 & Rp. & 70.020 .000 .00 \\
\hline 12 & Desember & 104.000 & Rp. & 72.820 .800 .00 \\
\hline \multicolumn{2}{c}{ Total jumlah } & 1.140 .000 & Rp. 798.228 .000 .00 \\
\hline
\end{tabular}

4.3 Analisis Break Event Point (BEP) Pada UKM Roti (rotiku rotimu) Desa

Berdasarkan data biaya tetap Fixed Cost (FC) dan biaya tidak tetap Variabel Cost (VC) yang telah didapatkan dalam pembuatan roti, selanjutnya akan digunakan sebagai data untuk menganalisa apakah usaha tersebut layak atau tidak layak ditinjau dari analisis Break Even Point (BEP).

Tabel 4.5 Rata-rata pengeluaran (TC) dan pendapatan (TR) dalam pembuatan roti goreng pada perusahaan roti (rotiku rotimu) Perhitungan:

\begin{tabular}{lrll}
\hline Bulan & $\begin{array}{l}\text { Jumlah } \\
\text { rata-rata } \\
\text { roti yang } \\
\text { dihasilkan } \\
\text { (buah) } \\
\text { (Akumulasi) }\end{array}$ & $\begin{array}{l}\text { Biaya total Total } \\
\text { Cost (TC) } \\
\text { (Akumulasi) }\end{array}$ & $\begin{array}{l}\text { Total pendapatan } \\
\text { (TR) (Akumulasi) }\end{array}$ \\
\hline Januari & 0 & Rp. 30.250.733,33 & Rp. \\
\hline Februari & 190.000 & Rp. 163.288.733,33 & Rp. 152.000.000,00 \\
\hline Maret & 285.000 & Rp. 229.807.733,33 & Rp. 228.000.000,00 \\
\hline April & 380.000 & Rp. 296.326.733,33 & Rp. 304.000.000,00 \\
\hline Mei & 475.000 & Rp. 362.845.733,33 & Rp. 380.000.000,00 \\
\hline Juni & 570.000 & Rp. 429.364.733,33 & Rp. 456.000.000,00 \\
\hline Juli & 665.000 & Rp. 495.883.733,33 & Rp. 532.000.000,00 \\
\hline Agustus & 760.000 & Rp. 562.402.733,33 & Rp. 608.000.000,00 \\
\hline September & 855.000 & Rp. 628.921.733,33 & Rp. 684.000.000,00 \\
\hline Oktober & 950.000 & Rp. 695.440.733,33 & Rp. 760.000.000,00 \\
\hline November & 1.045 .000 & Rp. 761.959.733,33 & Rp. 836.000.000,00 \\
\hline Desember & 1.140 .000 & Rp. 828.478.733,33 & Rp. 912.000.000,00 \\
\hline
\end{tabular}

Harga jual per roti $(\mathrm{p})=\frac{T R}{\text { Jumlah rot } i}$

$$
\begin{aligned}
& =\frac{R p \cdot 912 \cdot 000 \cdot 000,00}{1.140 .000} \\
& =\text { Rp. } 800
\end{aligned}
$$

Biaya tidak tetap per roti $(\mathrm{c})=\frac{V C}{\text { Jumlah rot } i}$

$$
\begin{aligned}
& =\frac{R p \cdot 798 \cdot 228 \cdot 000,00}{1 \cdot 140 \cdot 000} \\
& =\operatorname{Rp} \cdot 700,20
\end{aligned}
$$

Biaya tetap (FC) = Rp. 30.250.733,33 Jumlah roti yang dijual untuk mencapai titik impas adalah:

$$
\begin{aligned}
\operatorname{BEP}(\mathrm{x}) & =\frac{F C}{p-c} \\
& =\frac{R p \cdot 30 \cdot 250 \cdot 733,33}{R p \cdot 800-R p \cdot 700,20} \\
& =\frac{R p \cdot 30 \cdot 250 \cdot 733,33}{R p \cdot 99,80}
\end{aligned}
$$

$\operatorname{BEP}(x)=303.113,56$ roti $\approx 303.114$ roti Total biaya produksi untuk mencapai titik impas adalah:

$$
\begin{aligned}
& \mathrm{TC}= \text { Jumlah biaya tetap }+ \text { Biaya produksi } \\
& \mathrm{FC}= \operatorname{Rp} 30.250 .733,33 \\
& \mathrm{VC}= \mathrm{c} . \mathrm{X} \\
&= \mathrm{Rp} 700,20 \times 303.113,56 \\
&= \mathrm{Rp} 212.240 .114,71 \\
& \mathrm{TC}= \mathrm{FC}+\mathrm{VC} \\
&= \mathrm{Rp} .30 .250 .733,33+\mathrm{Rp} .212 .240 .114,71 \\
&= \text { Rp } 242.490 .848,04 \\
& \text { Berdasarkan tabel } 4.5 \text { dapat dibuat } \\
& \text { grafik Break Even Point perusahaan roti }
\end{aligned}
$$


(rotiku rotimu) Desa Babakan seperti pada gambar 4.1

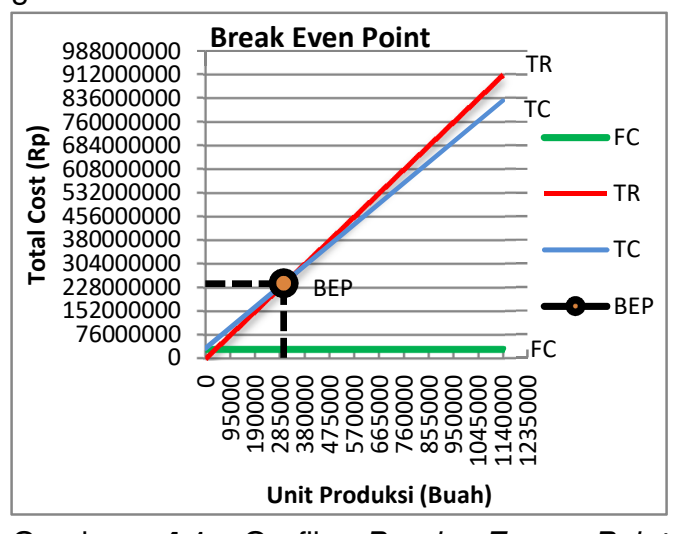

Gambar 4.1 Grafik Break Even Point perusahaan roti (rotiku rotimu) Desa Babakan

Berdasarkan hasil perhitungan analisis break event point pada pembuatan roti (rotiku rotimu) didapatkan jumlah roti yang harus diproduksi untuk mencapai nilai titik impas (Break Even Point) dengan biaya tetap (Fixed Cost) (FC) Rp.30.250.733,33 dan biaya tidak tetap (Variabel Cost) (VC) Rp.212.240.114,71 pada jumlah roti yang dihasilkan adalah 303.114 buah roti pada bulan ke 4 dengan Total Cost (TC) Rp.242.490.848,04. Pada titik ini perusahaan roti (Rotiku Rotimu) tidak mengalami kerugian dan tidak pula mendapat keuntungan, sehingga perusahaan roti ini dinyatakan layak beroperasi.

\subsection{Break Even Point Bila Harga Jual Rot Goreng Dengan Penurunan 6,25\% atau Dengan Harga $R p$ 750,00 , dan Dengan Kenaikan 6,25\% atau Dengan Harga Rp 850,00}

Berdasarkan data biaya tetap Fixed Cost (FC) dan biaya tidak tetap Variabel Cost (VC) yang telah didapatkan dalam pembuatan roti, selanjutnya akan digunakan sebagai data untuk menganalisa pengaruh Break Even Point (BEP) bila harga jual roti goreng difariasikan. Analisa ini penting dilakukan untuk memberikan rekomendasi bagi pelaku usaha sehingga pelaku usaha dapat mengetahui kapan dan berapa jumlah produk yang dihasilkan apabila harga jual roti goreng dengan penurunan $6,25 \%$ atau dengan harga $\mathrm{Rp} 750,00$,dan dengan kenaikan $6,25 \%$ atau dengan harga $R p$ 850,00 .

1. Penurunan harga jual roti goreng $6,25 \%$ atau dengan harga $\mathrm{Rp} 750,00$

Tabel 4.6 Rata-rata pendapatan (TR) Total Revenue dengan penurunan harga jual roti goreng $6,25 \%$ atau dengan harga $\mathrm{Rp} 750,00$ pada perusahaan roti (rotiku rotimu)

\begin{tabular}{|c|c|c|c|}
\hline Bulan & $\begin{array}{l}\text { Jumlah } \\
\text { rata-rata } \\
\text { roti yang } \\
\text { dihasilkan } \\
\text { (buah) } \\
\text { (Akumulasi) }\end{array}$ & $\begin{array}{l}\text { Biaya total Total } \\
\text { Cost (TC) } \\
\text { (Akumulasi) }\end{array}$ & $\begin{array}{l}\text { Total pendapatan } \\
\text { (TR) (Akumulasi) }\end{array}$ \\
\hline & 0 & Rp $30.250 .733,33$ & $\mathrm{Rp}$ \\
\hline Januari & 95.000 & Rp 96.769.733,33 & Rp $71.250 .000,00$ \\
\hline Februari & 190.000 & Rp163.288.733,33 & Rp142.500.000,00 \\
\hline Maret & 285.000 & Rp229.807.733,33 & Rp213.750.000,00 \\
\hline April & 380.000 & Rp296.326.733,33 & Rp285.000.000,00 \\
\hline Mei & 475.000 & Rp362.845.733,33 & Rp356.250.000,00 \\
\hline Juni & 570.000 & Rp429.364.733,33 & Rp427.500.000,00 \\
\hline Juli & 665.000 & Rp495.883.733,33 & Rp498.750.000,00 \\
\hline Agustus & 760.000 & Rp562.402.733,33 & Rp570.000.000,00 \\
\hline September & 855.000 & Rp628.921.733,33 & Rp641.250.000,00 \\
\hline Oktober & 950.000 & Rp695.440.733,33 & Rp712.500.000,00 \\
\hline November & 1.045 .000 & Rp761.959.733,33 & Rp783.750.000,00 \\
\hline Desember & 1.140 .000 & Rp828.478.733,33 & Rp855.000.000,00 \\
\hline
\end{tabular}

Biaya tidak tetap per roti $(\mathrm{c})=\frac{V C}{\text { Jumlah roti }}$

$$
=\frac{R p \cdot 798 \cdot 228.000,00}{1.140 .000}
$$

$=$ Rp. 700.200

Biaya tetap $(F C) \quad=$ Rp. $30.250 .733,33$ Jumlah roti yang dijual untuk mencapai titik impas dengan harga jual roti goreng $\mathrm{Rp}$ 750,00 adalah :

$$
\begin{aligned}
\operatorname{BEP}(\mathrm{x}) & =\frac{F C}{p-c} \\
& =\frac{R p \cdot 30 \cdot 250 \cdot 733,33}{R p \cdot 750-R p \cdot 700,20} \\
& =\frac{R p \cdot 30 \cdot 250 \cdot 733,33}{R p \cdot 149,80}
\end{aligned}
$$

$\operatorname{BEP}(x)=607.444,44$ roti $\approx 607.444$ roti Total biaya produksi untuk mencapai titik impas adalah:

TC = Jumlah biaya tetap + Biaya produksi

$F C=R p 30.250 .733,33$

$\mathrm{VC}=\mathrm{c} . \mathrm{X}$

$=\operatorname{Rp} 700,20 \times 607.444,44$

$=\operatorname{Rp~425.332.596,89~}$

$\mathrm{TC}=\mathrm{FC}+\mathrm{VC}$

$=$ Rp.30.250.733,33+Rp.425.332.596,89

$=$ Rp. $455.583 .330,22$

Berdasarkan tabel 4.6 dapat dibuat grafik Break Even Point dengan penurunan harga jual roti goreng $6,25 \%$ atau dengan harga $\mathrm{Rp} 750,00$ pada perusahaan roti (rotiku rotimu) Desa Babakan seperti pada gambar 4.2 


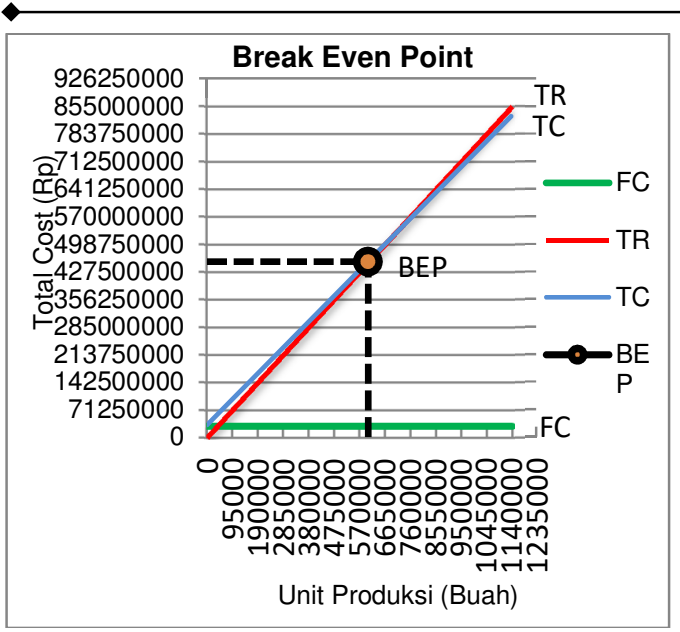

Gambar 4.2 Grafik Break Even Point dengan penurunan harga jual roti goreng $6,25 \%$ atau dengan harga Rp 750,00 pada perusahaan roti (rotiku rotimu) Desa Babakan

Berdasarkan hasil perhitungan analisis break even point dengan penurunan harga jual $6,25 \%$ atau dengan harga Rp.750 didapatkan jumlah roti yang harus diproduksi untuk mencapai titik impas adalah dengan biaya tetap (Fixed Cost) (FC) Rp.30.250.733,33 dan biaya tidak tetap (Variabel Cost) (VC) Rp.425.332.596.89 pada jumlah roti yang dihasilkan adalah 607.444 buah roti pada bulan ke 7 dengan Total Cost (TC) Rp.455.833.330,22.

2. Kenaikan harga jual roti goreng $6,25 \%$ atau dengan harga Rp.850,00

Tabel 4.7 Rata-rata pendapatan (TR) Total Revenue dengan kenaikan harga jual roti goreng $6,25 \%$ atau dengan harga $\mathrm{Rp} 850,00$ pada perusahaan roti (rotiku rotimu)

\begin{tabular}{|c|c|c|c|}
\hline Bulan & $\begin{array}{c}\text { Jumlah rata-rata roti } \\
\text { yang dihasilkan } \\
\text { (buah) (Akumulasi) }\end{array}$ & $\begin{array}{l}\text { Biaya total Total Cost } \\
\text { (TC) (Akumulasi) }\end{array}$ & $\begin{array}{l}\text { Total pendapatan } \\
\text { (TR) (Akumulasi) }\end{array}$ \\
\hline & 0 & Rp. $30.250 .733,33$ & Rp. - \\
\hline Januari & 95.000 & Rp. $96.769 .733,33$ & Rp. $80.750 .000,00$ \\
\hline Februari & 190.000 & Rp. 163.288.733,33 & Rp. $161.500 .000,00$ \\
\hline Maret & 285.000 & Rp. 229.807.733,33 & Rp. $242.250 .000,00$ \\
\hline April & 380.000 & Rp. 296.326.733,33 & Rp. $323.000 .000,00$ \\
\hline Mei & 475.000 & Rp. $362.845 .733,33$ & Rp. $403.750 .000,00$ \\
\hline Juni & 570.000 & Rp. 429.364.733,33 & Rp. $484.500 .000,00$ \\
\hline Juli & 665.000 & Rp. 495.883.733,33 & Rp. $565.250 .000,00$ \\
\hline Agustus & 760.000 & Rp. 562.402.733,33 & Rp. $646.000 .000,00$ \\
\hline September & 855.000 & Rp. 628.921.733,33 & Rp. $726.750 .000,00$ \\
\hline Oktober & 950.000 & Rp. 695.440.733,33 & Rp. $807.500 .000,00$ \\
\hline November & 1.045 .000 & Rp. 761.959.733,33 & Rp. 888.250.000,00 \\
\hline Desember & 1.140 .000 & Rp. 828.478.733,33 & Rp. $969.000 .000,00$ \\
\hline
\end{tabular}

Biaya tidak tetap per roti $(c)=\frac{V C}{\text { Jumlah roti }}$

$$
\begin{aligned}
& =\frac{R p \cdot 798 \cdot 228 \cdot 000,00}{1.140 .000} \\
& =\operatorname{Rp} \cdot 700.200
\end{aligned}
$$

Biaya tetap (FC) = Rp. 30.250.733,33 Jumlah roti yang dijual untuk mencapai titik impas dengan harga jual roti goreng $\mathrm{Rp}$ 850,00 adalah :

$$
\begin{aligned}
\operatorname{BEP}(\mathrm{x}) & =\frac{F C}{p-c} \\
& =\frac{R p \cdot 30 \cdot 250 \cdot 733,33}{R p \cdot 850-R p \cdot 700,20} \\
& =\frac{R p \cdot 30 \cdot 250 \cdot 733,33}{R p \cdot 149,80} \\
\operatorname{BEP}(\mathrm{x}) & =201 \cdot 940,81 \text { roti } \approx 201.941 \text { roti }
\end{aligned}
$$

Total biaya produksi untuk mencapai titik impas adalah:

$$
\begin{aligned}
& \mathrm{TC}=\text { Jumlah biaya tetap }+ \text { Biaya produksi } \\
& \mathrm{FC}=\mathrm{Rp} 30.250 .733,33 \\
& \mathrm{VC}= \mathrm{c} . \mathrm{X} \\
&=\mathrm{Rp} .700,20 \times 201.940 .81 \\
&=\mathrm{Rp} .141 .398 .955,16 \\
& \mathrm{TC}=\mathrm{FC}+\mathrm{VC} \\
&=\mathrm{Rp} .30 .250 .733,33+\mathrm{Rp} .141 .398 .955,16 \\
&=\text { Rp. } 171.649 .688,49 \\
& \text { Berdasarkan tabel } 4.7, \text { dapat dibuat } \\
& \text { grafik Break Even Point dengan kenaikan } \\
& \text { harga jual roti goreng } 6,25 \% \text { atau dengan } \\
& \text { harga Rp.850,00 pada perusahaan roti } \\
& \text { (rotiku rotimu) Desa Babakan seperti pada } \\
& \text { gambar } 4.3 .
\end{aligned}
$$




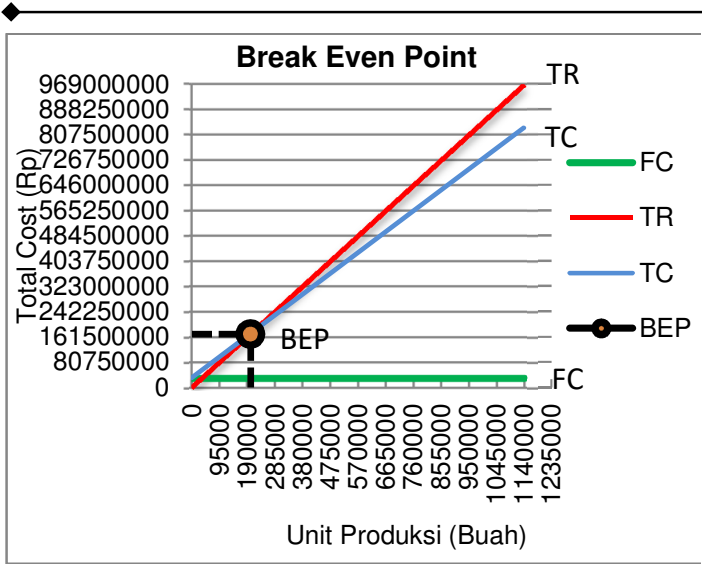

Gambar 4.3 Grafik Break Even Point dengan kenaikan harga jual roti goreng $6,25 \%$ atau dengan harga Rp.850,00 pada perusahaan roti (rotiku rotimu) Desa Babakan

Berdasarkan hasil perhitungan analisis break even point dengan kenaikan harga jual $6,25 \%$ atau dengan harga Rp.850 didapatkan jumlah roti yang harus diproduksi untuk mencapai titik impas adalah dengan biaya tetap (Fixed Cost) (FC) Rp.30.250.733,33 dan biaya tidak tetap (Variabel Cost) (VC) Rp.141.398.955,16 pada jumlah roti yang dihasilkan adalah 201.941 buah roti pada bulan ke 3 dengan Total Cost (TC) Rp.171.649.688,49.

4.5 Perbandingan Harga Jual Roti Goreng Dengan Harga Rp 750,00, Rp 800,00 dan $\operatorname{Rp} 850,00$

Berdasarkan perhitungan dari nilai Break Even Point dapat dilakukan perbandingan harga jual antara Rp.750,00, Rp.800,00 dan Rp.850,00 dalam penjualan roti goreng selama 1 Tahun. Adapun perbandingan pendapatan dapat dilihat pada gambar dibawah ini :

Tabel 4.8 Rata-rata pendapatan (TR) dengan harga jual Rp.750,00, Rp.800,00 dan Rp.850,00 dalam pembuatan roti goreng pada perusahaan roti (rotiku rotimu) Desa Babakan

Jumlah rata-

rata roti

yang dihasilkan

(buah)

(Akumulasi)

\begin{tabular}{|c|c|c|c|c|}
\hline 0 & $30.250 .733,33$ & Rp. & Rp. & Rp. \\
\hline 95000 & $96.769 .733,33$ & Rp. 71.250 .000 & Rp. 76.000 .000 & Rp. 80.750 .000 \\
\hline 190000 & Rp. $163.288 .733,33$ & Rp. 142.500 .000 & Rp. 152.000 .000 & Rp. 161.500 .000 \\
\hline 285000 & Rp. 229.807.733,33 & Rp. 213.750.000 & Rp. 228.000.000 & Rp. 242.250.000 \\
\hline 380000 & Rp. 296.326.733,33 & Rp. 285.000 .000 & Rp. 304.000 .000 & Rp. 323.000 .000 \\
\hline 475000 & Rp. 362.845.733,33 & Rp. 356.250.000 & Rp. 380.000 .000 & Rp. 403.750 .000 \\
\hline 570000 & Rp. 429.364.733,33 & Rp. 427.500 .000 & Rp. 456.000 .000 & Rp. 484.500 .000 \\
\hline 665000 & Rp. $495.883 .733,33$ & Rp. 498.750 .000 & Rp. 532.000 .000 & Rp. 565.250 .000 \\
\hline 760000 & Rp. 562.402.733,33 & Rp. 570.000.000 & Rp. 608.000 .000 & Rp. 646.000.000 \\
\hline 855000 & Rp. 628.921.733,33 & Rp. 641.250 .000 & Rp. 684.000 .000 & Rp. 726.750 .000 \\
\hline 950000 & Rp. $695.440 .733,33$ & Rp. 712.500 .000 & Rp. 760.000 .000 & Rp. 807.500 .000 \\
\hline 1045000 & Rp. 761.959.733,33 & Rp. 783.750 .000 & Rp. 836.000.000 & Rp. 888.250.000 \\
\hline 1140000 & Rp. 828.478.733,33 & Rp. 855.000.000 & Rp. 912.000.000 & Rp. 969.000 .000 \\
\hline
\end{tabular}

Dengan menggunakan tabel 4.8 diperoleh perhitungan sebagai berikut:

Rumus menghitung Pendapatan bersih (Net Revenue):

Net Revenue $=$ TR-TC

Dengan menggunakan data pada tabel 4.8 diperoleh hasil perhitungan sebagai berikut:
Net Revenue $=$ Rp. 0,00-Rp. 30.250.733,33

Net Revenue $=-$ Rp. $30.250 .733,33$

Dengan cara yang sama, maka diperoleh data pendapatan bersih (Net Revenue) penjualan roti goreng pada tabel 4.25 dibawah ini. 
Tabel 4.9 Rata-rata pendapatan bersih (Net Revenue) dengan harga jual Rp.750,00, Rp.800,00 dan $\mathrm{Rp} 850,00$ dalam pembuatan roti goreng pada perusahaan roti (rotiku rotimu) Desa Babakan

\begin{tabular}{|c|c|c|c|c|}
\hline Bulan & $\begin{array}{l}\text { Jumlah rata- } \\
\text { rata roti yang } \\
\text { dihasilkan } \\
\text { (buah) } \\
\text { (Akumulasi) }\end{array}$ & $\begin{array}{l}\text { Net Revenue } \\
\text { Rp } 750 \\
\text { (Akumulasi) }\end{array}$ & $\begin{array}{l}\text { Net revenue } \\
\text { Rp } 800 \\
\text { (Akumulasi) }\end{array}$ & $\begin{array}{l}\text { Net revenue Rp } 850 \\
\text { (Akumulasi) }\end{array}$ \\
\hline & 0 & Rp. -30.250 .733 .33 & Rp. -30.250 .733 .33 & Rp. -30.250 .733 .33 \\
\hline Januari & 95000 & Rp. -25.519.733.33 & Rp. -20.769 .733 .33 & Rp. -16.019 .733 .33 \\
\hline Februari & 190000 & Rp. -20.788 .733 .33 & Rp. -11.288 .733 .33 & $\begin{array}{ll}\text { Rp. } & -1.788 .733 .33 \\
\end{array}$ \\
\hline Maret & 285000 & Rp. -16.057 .733 .33 & Rp. -1.807 .733 .33 & Rp. 12.442 .266 .67 \\
\hline April & 380000 & Rp. -11.326 .733 .33 & $\begin{array}{ll}\text { Rp. } & 7.673 .266 .67\end{array}$ & Rp. 26.673.266.67 \\
\hline Mei & 475000 & Rp. -6.595 .733 .33 & Rp. 17.154.266.67 & Rp. 40.904 .266 .67 \\
\hline Juni & 570000 & Rp. -1.864 .733 .33 & Rp. 26.635.266.67 & Rp. 55.135 .266 .67 \\
\hline Juli & 665000 & $\begin{array}{ll}\text { Rp. } & 2.866 .266 .67\end{array}$ & Rp. 36.116.266.67 & $\begin{array}{ll}\text { Rp. } & 69.366 .266 .67\end{array}$ \\
\hline Agustus & 760000 & $\begin{array}{ll}\text { Rp. } & 7.597 .266 .67\end{array}$ & Rp. 45.597.266.67 & Rp. 83.597.266.67 \\
\hline September & 855000 & Rp. 12.328.266.67 & Rp. 55.078.266.67 & Rp. 97.828.266.67 \\
\hline Oktober & 950000 & Rp. 17.059.266.67 & Rp. 64.559.266.67 & Rp. 112.059 .266 .67 \\
\hline November & 1045000 & Rp. 21.790.266.67 & Rp. 74.040.266.67 & Rp. 126.290.266.67 \\
\hline Desember & 1140000 & Rp. 26.521.266.67 & Rp. 83.521.266.67 & Rp. 140.521.266.67 \\
\hline
\end{tabular}

Berdasarkan tabel 4.25 , dapat dibuat grafik perbandingan harga jual roti goreng pada gambar 4.4 dibawah ini :

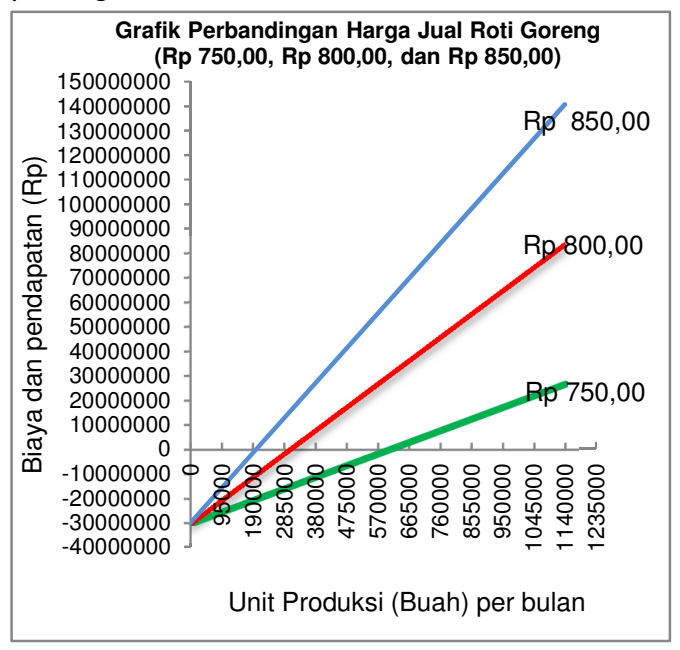

Gambar 4.4 Grafik perbandingan harga jual roti goreng

Berdasarkan grafik tersebut dapat diketahui pada saat tidak melakukan produksi pembuatan roti goreng, dengan harga jual Rp 750,00, Rp 800,00, dan Rp850,00 mengalami kerugian yang sama yaitu sebesar $R p$ 30.250.733,33 sebab sama-sama memiliki biaya yang sama besar. Pada saat produksi dibawah 201.941 buah roti dengan harga jual Rp 750,00, Rp 800,00, dan $\mathrm{Rp} 850,00$ tidak layak disebabkan pemilik industri masih mengalami kerugian. Pada saat produksi diatas 201.941 hingga 303.114 buah roti dengan harga jual $\mathrm{Rp}$
850,00 telah layak, harga jual $\mathrm{Rp} 800,00$ dan Rp 750,00 tidak layak disebabkan pada harga jual $\mathrm{Rp} 850,00$ sudah mendapatkan keuntungan sedangkan harga jual $\mathrm{Rp} 800,00$ dan Rp 750,00 masih mengalami kerugian. Pada saat produksi 303.114 hingga 1.140 .000 buah roti dengan harga jual $R p$ 800,00 lebih layak dibandingkan harga jual Rp 750,00 disebabkan keuntungan yang didapatkan pada harga jual $\mathrm{Rp} \mathrm{800,00} \mathrm{lebih}$ besar dibandingkan harga jual Rp 750,00.

4.6 Kondisi Break Even Point Bila Biaya Variabel di Turunkan Dengan Alternatif Pembelian Minyak Goreng di Agen Dengan Harga Rp 9.850,00 per Kilogram

Berdasarkan data biaya tetap Fixed Cost (FC), biaya tidak tetap Variabel Cost (VC) selain minyak goreng dan pendapatan dengan harga jual $\mathrm{Rp} \mathrm{800,00} \mathrm{yang} \mathrm{telah}$ didapatkan dalam pembuatan roti, selanjutnya akan digunakan sebagai data untuk menganalisa pengaruh Break Even Point (BEP) bila harga beli minyak goreng diturunkan dengan alternatif pembelian minyak goreng di agen dengan harga $R p$ $9.850,00$ per kilogram. Analisa ini penting dilakukan untuk memberikan rekomendasi bagi pelaku usaha sehingga pelaku usaha dapat mengetahui kapan dan berapa jumlah produk yang dihasilkan apabila biaya variabel di turunkan dengan alternatif harga pembelian minyak goreng di agen dengan harga $\mathrm{Rp} 9.850,00$ per kilogram. 
Tabel 4.10 Penurunan biaya tidak tetap (variabel cost) per roti dalam pembuatan roti goreng pada perusahaan roti (rotiku rotimu)

\begin{tabular}{lll}
\hline No & $\begin{array}{l}\text { Biaya tidak tetap (varibel } \\
\text { cost) }\end{array}$ & Nilai (Rp) \\
\hline 1 & Biaya bahan baku & \\
\hline 2 & Biaya pengoperasian alat & Rp. 102,81 \\
\hline 3 & Biaya gaji pegawai & Rp. 65,00 \\
\hline 4 & Biaya pengemasan & Rp. 95,00 \\
\hline & Total jumlah & Rp. 562,54 \\
\hline
\end{tabular}

c = biaya bahan baku+biaya pengoperasian alat+biaya gaji pegawai+biaya pengemasan

$=$ Rp.402,54+Rp.102,81+Rp.65,00+ Rp.95,00

$=$ Rp. 562,54 per roti

Biaya tidak tetap (varibel cost) dalam pembuatan satu buah roti (c) adalah:

Tabel 4.11 Rata-rata pengeluaran (TC) dan pendapatan (TR) dengan penurunan biaya tidak tetap (variabel cost) dalam pembuatan roti goreng pada perusahaan roti (rotiku rotimu)

\begin{tabular}{lrrl}
\hline Bulan & $\begin{array}{c}\text { Jumlah rata-rata roti } \\
\text { yang dihasilkan (buah) } \\
\text { (Akumulasi) }\end{array}$ & $\begin{array}{c}\text { Biaya total Total Cost } \\
\text { (TC) (Akumulasi) }\end{array}$ & $\begin{array}{c}\text { Total pendapatan } \\
\text { (TR) (Akumulasi) }\end{array}$ \\
\hline Januari & 0 & Rp. 30.250.733,33 & Rp. \\
\hline Februari & 95.000 & Rp. 83.692.033,33 & Rp. 76.000.000,00 \\
\hline Maret & 190.000 & Rp. 137.133.333,33 & Rp. 152.000.000,00 \\
\hline April & 285.000 & Rp. 190.574.633,33 & Rp. 228.000.000,00 \\
\hline Mei & 380.000 & Rp. 244.015.933,33 & Rp. 304.000.000,00 \\
\hline Juni & 475.000 & Rp. 297.457.233,33 & Rp. 380.000.000,00 \\
\hline Juli & 570.000 & Rp. 350.898.533,33 & Rp. 456.000.000,00 \\
\hline Agustus & 665.000 & Rp. 404.339.833,33 & Rp. 532.000.000,00 \\
\hline September & 760.000 & Rp. 457.781.133,33 & Rp. 608.000.000,00 \\
\hline Oktober & 855.000 & Rp. 511.222.433,33 & Rp. 684.000.000,00 \\
\hline November & 950.000 & Rp. 564.663.733,33 & Rp. 760.000.000,00 \\
\hline Desember & 1.045 .000 & Rp. 618.105.033,33 & Rp. 836.000.000,00 \\
\hline & 1.140 .000 & Rp. 671.546.333,33 & Rp. 912.000.000,00 \\
\hline
\end{tabular}

Jumlah roti yang dijual untuk mencapai titik impas adalah:

$$
\begin{aligned}
\operatorname{BEP}(\mathrm{x}) & =\frac{F C}{p-c} \\
& =\frac{R p \cdot 30 \cdot 250 \cdot 733,33}{R p \cdot 800-R p \cdot 562,54}
\end{aligned}
$$

$\operatorname{BEP}(x)=127.392,96$ roti $\approx 127.393$ roti

Total biaya produksi untuk mencapai titik impas adalah:

$\mathrm{TC}=$ Jumlah biaya tetap+Biaya produksi

$\mathrm{FC}=\mathrm{Rp} .30 .250 .733,33$

$\mathrm{VC}=\mathrm{c} . \mathrm{X}$

$=$ Rp. 562,54x127.392,96

$=$ Rp. 71.663.635,72

$\mathrm{TC}=\mathrm{FC}+\mathrm{VC}$

$=$ Rp. 30.250.733,33+Rp. 71.663.635,72

$=$ Rp. 101.914.369,05
Berdasarkan tabel 4.11 dapat dibuat grafik Break Even Point perusahaan roti (rotiku rotimu) Desa Babakan seperti pada gambar 4.5

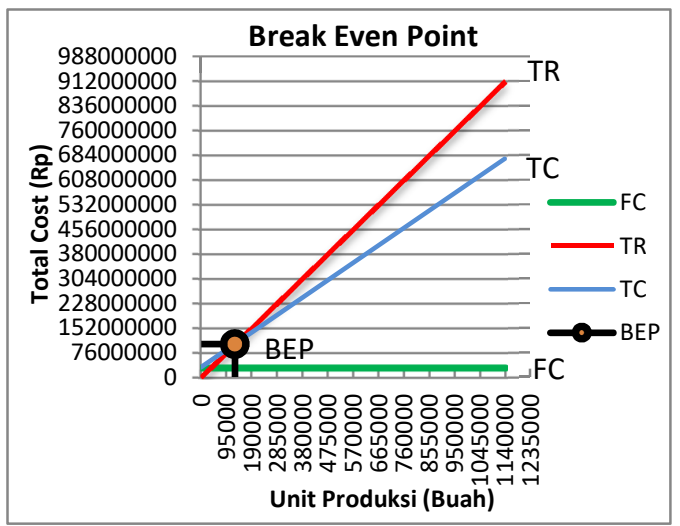


Gambar 4.5 Grafik Break Even Point dengan penurunan biaya tidak tetap (variabel cost) dengan harga jual roti goreng Rp. 800,00 pada perusahaan roti (rotiku rotimu) Desa Babakan

Berdasarkan hasil perhitungan analisis break event point pada pembuatan roti (rotiku rotimu) didapatkan jumlah roti yang harus diproduksi untuk mencapai nilai titik impas (Break Even Point) dengan biaya tetap (Fixed Cost) (FC) Rp. 30.250.733,33 dan biaya tidak tetap (Variabel Cost) (VC) Rp.71.663.635,72 pada jumlah roti yang dihasilkan adalah 127.393 buah roti pada bulan ke 2 dengan Total Cost (TC) Rp.101.914.369,05. Dengan menurunkan biaya pembelian minyak goreng mengakibatkan tingkat titik impas (Break Even Point) semakin cepat diperoleh sehingga pengusaha lebih cepat mendapatkan laba.

\section{KESIMPULAN DAN SARAN}

\subsection{Kesimpulan}

Dari analisis dan pembahasan diatas, maka dapat ditarik kesimpulan sebagai berikut:

1. Jumlah produk yang dihasilkan untuk mencapai kondisi Break Even Point (BEP) adalah berjumlah 301.701 buah roti.

2. Pada saat bulan keempat UKM roti (Rotiku Rotimu) telah mencapai break even point dengan total biaya pengeluaran (TC) sama dengan total pendapatan (TR) yaitu Rp.241.360.055,67.

3. UKM Roti (rotiku rotimu) dapat mencapai Break Even Point (BEP) dalam waktu 4 bulan sehingga UKM tersebut dinyatakan layak beroperasi.

4. Dengan adanya kenaikan harga jual roti goreng Rp.850,00 mengakibatkan kenaikan laba sebesar Rp.57.000.000,00 sedangkan pada harga jual roti goreng Rp.750,00 mengakibatkan penurunan laba sebesar Rp.57.000.000,00 disaat sama-sama memproduksi 1.140 .000 buah roti.

5. Dengan menurunkan biaya variabel, pengusaha dapat mempercepat pencapaian tingkat titik impas (Break Even Point).

\subsection{Saran}

1. Bagi pihak UKM roti (Rotiku Rotimu) Desa Babakan setelah mengetahui cara analisis BEP, diharapkan dapat mengaplikasikan analisis ini, melakukan pembukuan, pembagian biaya-biaya dan pendapatan yang diperoleh.
2. Diharapkan bagi pihak UKM dengan analisis ini usaha yang digeluti dapat lebih maju dan bersaing dengan perusahaanperusahaan ternama yang telah memiliki sertifikasi dari BPOM, MUI, dan lain-lain.

\section{DAFTAR PUSTAKA}

[1] Alwi, S., 1994, Alat-Alat Analisa Dalam Pembelanjaan, Edisi Revisi, Andi Offset, Yogyakarta

[2] Chaniago, H., 2008, Strategi Meningkatkan Daya Saing Usaha Kecil Menengah (UKM) di Indonesia, (diunduh pada hari jum'at 12 September 2014).

[3] Febriyandi, F., 2012, Aplikasi Break Even Point Pada Sistem Operasional Kapal Motor Penyeberangan Roditha PT. ASDP Indonesia Ferry (Persero) Cabang Lembar, Skripsi Jurusan Teknik Mesin Fakultas Teknik Universitas Mataram, Mataram.

[4] Halim, A., Bambang S., 1990, Akuntansi Manajemen, Edisi Pertama, BPFE, Yogyakarta.

[5] Harahap, S.S., 2008, Teori Akutansi, PT Raja Grafindo Persada, Jakarta.

[6] Hermawan, A.A., 2000, Akuntansi Manajemen Edisi 4. Erlangga. Jakarta.

[7] Himayati, R., 2010, Studi Kelayakan Penggunaan Mesin Diesel Berdasarkan Metode Break Even Point (BEP) Pada PLTD Labuhan Sumbawa, Skripsi Jurusan Teknik Mesin Fakultas Teknik Universitas Mataram, Mataram.

[8] Marhaeni, A.P., 2011, Analisis Break Even Point Sebagai Alat Perencanaan Laba Pada Industri Kecil Tegal Di Kecamatan Pendurungan Periode 2004-2008 (Studi Kasus Usaha Manufaktur), Fakultas Ekonomi Universitas Diponegoro, Semarang.

[9] Pujawan,I.N., 2004, Ekonomi Teknik, Guna Widya, Surabaya.

[10] Sadeli, L., dan Bedjo, S., Akuntansi Manajemen, PT Bumi Aksara, Jakarta.

[11] Sigit, S., 1990, Analisa Break Even, Edisi Ketiga, BPFE, Yogyakarta.

[12] Tambunan, T., 2012, Ukuran Daya Saing Koperasi dan UKM, https://ariesulistya. wordpress. Com/ 2012/12/22/186/ (diunduh pada hari Rabu 12 November 2014).

[13] Wijana, M., dan Joniarta, I.W., 2013, Ipteks Bagi Masyarakat Usaha Roti di Kelurahan Babakan Kota Mataram, Laporan Akhir Program Ipteks Bagi Masyarakat, Universitas Mataram. 